\title{
Pengembangan Hipotetik Modul Bimbingan dan Konseling tentang Kesehatan Reproduksi Remaja Perempuan
}

\author{
Gita Afriani ${ }^{1}$, Evi Afiati ${ }^{2}$, Putri Dian Dia Conia ${ }^{3}$ \\ ${ }^{123}$ Program Studi Bimbingan dan Konseling, Fakultas Keguruan dan Ilmu Pendidikan, \\ Universitas Sultan Ageng Tirtayasa \\ gitaafr@gmail.com ${ }^{1}$ \\ eviafiati@untirta.ac.id ${ }^{2}$ \\ putriconia@untirta.ac.id ${ }^{3}$
}

\begin{abstract}
Abstrak
Media memiliki peran penting dalam pemberian layanan bimbingan dan konseling kepada siswa. Penelitian ini bertujuan mengembangkan media bimbingan dan konseling dalam bentuk modul tentang kesehatan reproduksi remaja perempuan. Tujuannya untuk membantu guru bimbingan dan konseling dalam memberikan informasi, serta menarik minat siswa belajar tentang kesehatan reproduksi remaja perempuan. Metode yang digunakan dalam penelitian adalah penelitian pengembangan (R\&D) model Borg \& Gall. Model Borg \& Gall di sederhanakan menjadi tujuh tahap yaitu, potensi dan masalah, pengumpulan data, desain produk, validasi desain, revisi desain, uji coba produk, revisi produk awal. Uji validasi modul dilakukan oleh satu orang ahli media dan satu orang ahli materi. Sementara, untuk uji coba produk dilakukan kepada 30 siswa sebagai calon pengguna modul. Hasil uji validasi yang dilakukan mencapai $81 \%$ oleh ahli materi, $83 \%$ oleh ahli media, dan $89 \%$ oleh siswa. Berdasarkan uji validasi dan produk yang telah dilakukan dapat disimpulkan bahwa modul bimbingan dan konseling kesehatan reproduksi remaja perempuan layak diimplementasikan kepada siswa.
\end{abstract}

Kata Kunci: Modul Bimbingan dan Konseling; Kesehatan Reproduksi; Remaja Perempuan.

\section{PENDAHULUAN}

Remaja perempuan adalah individu berusia 10 sampai 24 tahun yang dalam perkembangannya mengalami perubahan baik secara fisik, kognitif, sosial dan emosional termasuk juga perubahan dalam kesehatan reproduksi. Sesuai dengan pernyataan Santrock (2003) bahwa remaja merupakan masa transisi dari masa anak ke masa dewasa yang didalamnya terjadi perubahan-perubahan. Perubahan tersebut mencakup perubahan emosional, sosial, fisik dan kognitif. Masa peralihan merupakan periode krisis identitas diri. Banyak permasalahan yang muncul akibat dari rasa ingin tahu yang tinggi serta adanya pengaruh lingkungan sosial. Kesehatan reproduksi remaja merupakan salah satu isu 
permasalahan yang dihadapi remaja. Perkembangan fisik dan mental remaja yang secara alami memiliki dorongan dan hasrat seksual pada diri remaja, menjadi salah satu faktor remaja menghadapi masalah kesehatan reproduksi.

BKKBN (2001) mendefinisikan kesehatan reproduksi remaja adalah keadaan sejahtera dan sempurna baik mental, sosial dan fisik secara utuh, tidak hanya bebas dari penyakit dan kecacatan yang berkaitan dengan fungsi, sistem dan proses reproduksi sehingga memiliki hidup yang lebih produktif. Jadi, remaja dikatakan memiliki kesehatan reproduksi yang sehat bukan hanya dilihat dari fisik, tetapi dilihat juga dari perilaku remaja itu sendiri. Pemahaman mengenai kesehatan reproduksi remaja merupakan upaya untuk membantu remaja agar memiliki sikap pengetahuan, kesadaran serta perilaku kehidupan reproduksi yang sehat dan bertanggung jawab. Perilaku reproduksi sehat adalah perilaku sadar atas perilaku seksual dan dapat melindungi diri dari ancaman terhadap alat reproduksinya.

Remaja perempuan memiliki risiko lebih tinggi dibanding dengan remaja laki-laki terhadap masalah kesehatan reproduksi. Risiko tersebut karena remaja perempuan mempunyai alat reproduksi yang rumit dibanding dengan laki-laki. Selain itu, penyakit tentang kesehatan reproduksi yang dapat diderita oleh perempuan lebih banyak jika dibanding dengan laki-laki. Perempuan akan mengalami keadaan yang sangat tidak menguntungkan ketika mengalami permasalahan kesehatan reproduksi dimasa remaja baik secara fisik, mental, sosial dan ekonomi. Maka dari itu, pemahaman tentang kesehatan reproduksi sangat diperlukan oleh remaja perempuan. Pemahaman tentang kesehatan reproduksi remaja perempuan terlihat dari pengetahuan remaja perempuan mengenai alat, fungsi dan proses reproduksi serta perilaku-perilaku yang mempengaruhi kesehatan reproduksinya. Permasalahan kesehatan reproduksi yang dihadapi perempuan meliputi masalah reproduksi, seksualitas dan gender, kehamilan tidak diinginkan, kekerasan terhadap perempuan, dan infeksi menular seksual (Winarti, 2017).

Berdasarkan Survei Kinerja dan Akuntabilitas Program (SKAP) KKBPK remaja tahun 2019, sebanyak 0,6\% perempuan di Banten telah melakukan hubungan seksual sebelum menikah. Remaja perempuan yang telah melakukan hubungan seksual berisiko mengalami kehamilan. Remaja yang hamil, berisiko meninggal saat mengandung dan melahirkan di usia muda. Kondisi rahim yang belum sempurna dapat menyebabkan risiko kanker rahim dan trauma fisik pada organ intim. Selain itu, aborsi tidak aman juga dilakukan remaja perempuan yang mengalami kehamilan tidak diinginkan. Data menyebutkan bahwa angka aborsi remaja perempuan mencapai $2-2,6$ juta kasus atau 58\% remaja perempuan yang hamil di luar nikah berupaya melakukan aborsi. Tingginya angka permasalahanpermasalahan tersebut menunjukan fakta yang memprihatinkan, terlebih realita ini dialami generasi muda sebagai generasi bangsa (BKKBN; BPS; \& Kemkes, 2018).

Berdasarkan hasil asesmen menggunakan angket kebutuhan peserta didik di SMP Negeri 4 Kota Serang, item pernyataan "Saya merasa masih sedikit pemahaman tentang kesehatan reproduksi" menunjukan hasil dengan kategori tinggi yaitu $2.73 \%$. Selain itu, item pernyataan "Saya malu jika membicarakan masalah seks dan pacar kepada orang tua" 
menunjukkan persentase sebanyak 3.31\%. Kurangnya informasi yang diterima oleh siswa diduga sebagai salah satu faktor masih banyaknya siswa yang belum paham tentang kesehatan reproduksi. Hal tersebut didukung dengan tingginya jumlah responden yang mengatakan mereka malu untuk membicarakan masalah seks dan pasangan kepada orang tua. Hal tersebut dikarenakan salah satu ciri remaja adalah ingin menjadi mandiri dengan cara melepaskan diri dari pengaruh orang tua dan ketergantungan emosional. Sehingga remaja jarang sekali untuk melakukan diskusi dengan orang tuanya (Kusmiran, 2011).

Fakta di atas menunjukan bahwa remaja perempuan membutuhkan informasi yang menyeluruh mengenai kesehatan reproduksi. Selain orang tua, pemberian pemahaman mengenai kesehtan reproduksi remaja juga dapat dilakukan oleh pihak sekolah tepatnya oleh guru bimbingan dan konseling. Akan tetapi, pelaksanaan layanan bimbingan dan konseling di sekolah sering kali kurang berjalan efektif, contohnya di SMP Negeri 4 Kota Serang guru bimbingan dan konseling tidak memperoleh jam mengajar di kelas, sehingga guru bimbingan dan konseling memiliki kesulitan, keterbatasan waktu serta media yang terbatas dalam memberikan layanan informasi kepada siswa.

Salah satu upaya yang dapat dilakukan adalah dengan melakukan pengembangan media layanan informasi kepada siswa adalah dengan melakukan pengembangan media, misalnya dengan membuat modul sebagai sarana dalam pemberian informasi. Depdiknas (2008) menjelaskan modul adalah prangkat pembelajaran yag berisi materi dan metode yang telah disusun sistematis dan menarik agar mampu mencapai kompetensi yang diharapkan. Modul disajikan agar siswa mampu mempelajari materi secara individual sesuai dengan kemampuan belajarnya masing-masing dalam memahami isi pelajaran secara efektif dan efisien. Kelebihan modul ini antara lain adalah kemampuan menyajikan pesan atau nformasi dalam jumlah besar yang dapat dipelajari siswa sesuai dengan minat, kebutuhan dan kecepatan masing-masing. Selain itu karena modul ini mudah dibawa-bawa sehingga dapat dipelajari kapan saja dan dimana saja (Rosyidah \& Lukitaningsih, 2014).

Kemudahan menggunakan modul sebagai sumber informasi diharapkan membantu siswa dalam memahami tentang kesehatan reproduksi remaja perempuan. Berdasarkan uraian permasalahan di atas, penulis tertarik melakukan penelitian dengan judul "Pengembangan Hipotetik Modul Bimbingan dan Konseling tentang Kesehatan Reproduksi Remaja Perempuan" (Research and Development pada siswi kelas IX SMP Negeri Kota 4 Kota Serang Tahun Ajaran 2020/2021).

\section{METODE PENELITIAN}

Metode yang digunakan dalam penelitian adalah Penelitian dan Pengembangan (Research and Development). Menurut Sugiyono (2008) penelitian pengembangan merupakan metode penelitian yang digunakan untuk mengembangkan atau memvalidasi produk yang digunakan dalam pembelajaran dan pendidikan. Penelitian dan pengembangan yang dilakukan mengikuti pedoman yang dikembangkan oleh Borg \& Gall. Akan tetapi, penelitian yang dilakukan oleh peneliti termasuk penelitian pengembangan skala kecil 
(Small-Scale $R \& D)$, karena penelitian tersebut dilakukan hanya menggunakan beberapa tahapan.

Hal tersebut sudah ditegaskan oleh peneliti bahwa penelitian pengembangan hanya sampai tahap hipotetik. Dikatakan hipotetik, karena keefektifannya belum terbukti, dan baru bisa diketahui setelah dilakukan pengujian (Tjalla, Komalasari, \& Asharika, 2016). Penelitian pengembangan Borg and Gall memiliki sepuluh tahapan, akan tetapi yang dilakukan peneliti hanya sampai tahapan ke tujuh. Tahapan pengembangan meliputi potensi dan masalah, pengumpulan data, desain produk awal, validasi desain, revisi desain, uji produk, revisi produk awal.

Metode pengumpulan data dilakukan dengan cara studi literatur dan kuesioner. Studi literatur adalah proses meneliti buku dan bentuk tulisan lainnya untuk memperoleh bahan dan informasi teoritis yang berkaitan dan erat kaitannya dengan masalah kesehatan reproduksi remaja perempuan. Kuesioner digunakan bertujuan untuk melakukan uji validasi dan uji produk awal. Adapun indikator instrumen yang dibuat masing-masing untuk ahli media dan ahli materi, di adaptasi dari komponen penilaian bahan ajar yang disusun oleh Badan Standar Nasional Pendidikan. Indikator uji validasi ahli materi meliputi aspek kelayakan isi dan penyajian, sedangkan indikator uji validasi ahli media meliputi aspek kelayakan kegrafikaan dan bahasa. Indikator yang digunakan untuk melakukan uji coba produk kepada 30 orang siswa sebagai calon pengguna meliputi isi modul, desain modul dan bahasa.

Hasil uji validasi ahli dan uji produk awal berupa data kuantitatif dan kualitatif. Data kuantitatif yang diperoleh baik dari uji validasi oleh ahli materi maupun ahli media, dianalisis. Analisis dilakukan dengan menghitung persentase kelayakan dan diinterpretasikan sesuai dengan kriteria validitas perangkat penilaian. Persentase kelayakan ditentukan dengan rumus sebagai berikut:

$$
\text { Persentase Kelayakan }=\frac{\text { Skor yang diperoleh }}{\text { Skor yang diharapkan }} \times 100 \%
$$

Hasil yang diperoleh diintepretasikan berdasarkan kriteria perangkat penilaian menurut Sugiyono (2008) yang dapat dilihat pada tabel 1.

Tabel 1. Kriteria Validitas Perangkat Penilaian

\begin{tabular}{l|c|c}
\hline No & $\begin{array}{c}\text { Tingkat pencapaian } \\
\text { Kualifikasi }\end{array}$ & Keterangan \\
\hline 1. & $86 \%-100 \%$ & Sangat Layak \\
\hline 2 & $76 \%-85 \%$ & Layak \\
\hline 3 & $56 \%-75 \%$ & Cukup Layak \\
\hline 4 & $<55 \% \%$ & Kurang Layak \\
\hline
\end{tabular}




\section{HASIL DAN PEMBAHASAN}

Penelitian dilakukan secara garis besar terdiri dari dua tahap yaitu penelitian pendahuluan dan penelitian pengembangan. Penelitian pendahuluan yaitu proses menganalisis potensi, masalah dan mengumpulkan data. Selanjutnya dilakukan penelitian pengembangan sebagai tindak lanjut penelitian pendahuluan. Secara rinci hasil penelitian dan pengembangan akan dijelaskan sebagai berikut :

\section{Penelitian Pendahuluan dan Pengumpulan Data}

\section{a. Penelitian Pendahuluan}

Penelitian pendahuluan dilakukan untuk mengetahui gambaran pengetahuan siswa mengenai masalah kesehatan reporduksi yang disusun berdasarkan teori Winarti (2017) dengan indikator reprodukis, gender dan seksualitas, kehamilan tidak diinginkan, kekerasan pada perempuan dan infeksi menular seksual. Hasilnya secara keseluruhan tingkat pengetahuan siswa berada kategori sedang. Penelitian pendahuluan juga dilakukan untuk menganalisis potensi dan masalah di lokasi penelitian.

Salah satu potensi yang dimiliki SMP Negeri 4 Kota Serang adalah adanya dukungan dan minat dari guru bimbingan dan konseling serta kesiswaan mengenai topik kesehatan reproduksi. Sedangkan salah satu masalah yang dihadapi adalah waktu layanan bimbingan dan konsling yang terbatas karena guru bimbingan dan konseling tidak mendapat jam mengajar di kelas serta belum terdapat modul mengenai kesehatan reproduksi remaja yang dirancang secara khusus untuk diberikan kepada siswa perempuan.

\section{b. Pengumpulan Data}

Pengumpulan data merupakan studi literatur untuk mencari informasi bersumber dari jurnal, buku, modul dan artikel. Tahap pengumpulan data hasil gambaran pengetahuan siswa sesuai indikator. Peneliti melakukan analisis terhadap indikator yang memiliki frekuensi tinggi lebih sedikit dibanding dengan indikator lainnya. Serta indikator yang memiliki frekuensi rendah paling banyak dibanding indikator lainnya. Hasilnya indikator yang frekuensi tingginya sedikit adalah seksualitas dan gender. Sedangkan indikator dengan frekuensi rendah paling banyak adalah indikator reproduksi.

\section{Desain Produk Awal}

Produk yang dikembangkan berupa modul dengan judul "Modul Kesehatan Reproduksi Remaja Perempuan" secara keseluruhan terdapat sepuluh pembahasan dalam modul. Setelah menentukan tujuan pembelajaran, draft modul didesain menggunakan aplikasi Canva Pro. Terdapat beberapa konten dalam modul selain berisi materi adapula lembar aktivitas, quotes, dan evaluasi di akhir modul agar pengguna modul dapat melakukan evaluasi terhadap materi yang telah dipelajari.

\section{Uji Validasi}

Proses menguji kelayakan produk penelitian disebut uji validasi produk. Uji validasi dilakukan menggunakan instrumen penilaian terhadap modul kesehatan reproduksi remaja perempuan. Instrumen penilaian yang digunakan diadaptasi dari komponen penilaian bahan 
ajar yang disusun oleh Badan Standar Nasional Pendidikan. Uji validasi produk dilakukan oleh dua ahli yaitu ahli materi dan ahli media. Adapun validaro dan hasil uji validasi pada produk penelitian sebagai berikut :

\section{a. Ahli Materi}

Validator ahli materi yang dipilih peneliti adalah Ibu Yenie Wulandari, S.Sos selaku Widyaiswara BKKBN Provinsi Banten. Beliau dipilih karena memiliki kompetensi pada bidang kesehatan reproduksi remaja serta berpengalaman dengan penyusunan modul kesehatan reproduksi remaja. Hasil uji validasi kelayakan materi modul kesehatan reproduksi remaja perempuan dapat dilihat pada tabel 2 .

Tabel 2. Hasil Uji Validasi Ahli Materi

\begin{tabular}{ccccc}
\hline $\begin{array}{c}\text { Aspek } \\
\text { Penilaian }\end{array}$ & $\begin{array}{c}\text { S Skor } \\
\text { Diperoleh }\end{array}$ & $\begin{array}{c}\text { SSkor } \\
\text { Maks }\end{array}$ & $\begin{array}{c}\text { Persentase } \\
\text { Kelayakan }\end{array}$ & Kategori \\
\hline Kelayakan Isi & 20 & 25 & $80 \%$ & Layak \\
\hline $\begin{array}{c}\text { Kelayakan } \\
\text { Penyajian }\end{array}$ & 41 & 50 & $82 \%$ & Layak \\
\hline $\begin{array}{c}\text { Total } \\
\text { Keseluruhan }\end{array}$ & 61 & 75 & $81 \%$ & Layak \\
\hline
\end{tabular}

Selain itu, data kualitatif atau catatan yang diberikan ahli materi antara lain sebagai berikut.

1) Untuk definisi sebaiknya diberikan sumber rujukan.

2) Jika terdapat singkatan sebaiknya diberikan sedikit penjelasan terkait hal tersebut.

3) Untuk sesi menstruasi sebaiknya ditambahkan informasi mengapa harus mengganti pembalut dikarenakan masih banyak remaja yang enggan atau risih menggantinya di Sekolah.

4) Penjelasan mengenai stunting lebih diperjelas.

5) Sesi tindakan seksual masukan UU terkait hal tersebut agar dapat menguatkan posisi tindakan seksual sebagai sesuatu yang harus dianggap serius.

6) Akan lebih baik jika modul ditingkatkan dalam bentuk E-Modul agar lebih interaktif dengan memasuka video atau podcast/suara.

\section{b. Ahli Media}

Validator ahli media yang dipilih peneliti adalah Bapak Alfiandy Warih Handoyo, M.Pd selaku Dosen Jurusan Bimbingan dan Konseling Universitas Sultan Ageng Tirtayasa. Beliau dipilih karena memiliki kompetensi dalam media layanan bimbingan dan konseling. Aspek penilaian kelayakan pada validasi media modul meliputi kelayakan kegrafikaan dan kelayakan bahasa. Hasil uji validasi kelayakan media modul kesehatan reproduksi remaja perempuan dapat dilihat pada tabel 3. 
Tabel 3. Hasil Uji Validasi Ahli Media

\begin{tabular}{ccccc}
\hline $\begin{array}{c}\text { Aspek } \\
\text { Penilaian }\end{array}$ & $\begin{array}{c}\sum \text { Skor } \\
\text { Diperoleh }\end{array}$ & $\begin{array}{c}\sum \text { Skor } \\
\text { Maks }\end{array}$ & $\begin{array}{c}\text { Persentase } \\
\text { Kelayakan }\end{array}$ & Kategori \\
\hline $\begin{array}{c}\text { Kelayakan } \\
\text { Kegrafikaan }\end{array}$ & 69 & 80 & $86 \%$ & $\begin{array}{c}\text { Sangat } \\
\text { Layak }\end{array}$ \\
\hline $\begin{array}{c}\text { Kelayakan } \\
\text { Bahasa }\end{array}$ & 31 & 40 & $78 \%$ & Layak \\
\hline $\begin{array}{c}\text { Total } \\
\text { Keseluruhan }\end{array}$ & 100 & 120 & $83 \%$ & Layak \\
\hline
\end{tabular}

Selain itu, data kualitatif atau catatan yang diberikan ahli media antara lain sebagai berikut.

1) Sudah bagus dan menarik apalagi full color.

2) Kuis dikurangi dan dibuat lebih interaktif dengan ditautkan menjadi link google form.

3) Mengubah materi menjadi video agar konten dalam modul bervariasi.

\section{Revisi Produk}

Revisi produk dikerjakan atas dasar catatan yang diberikan ahli materi dan ahli media ketika uji validasi kelayakan modul. Produk yang telah direvisi ditinjau kembali oleh ahli, sebelum akhirnya dinyatakan layak untuk di uji coba. Beberapa revisi yang dilakukan antara lain sebagai berikut.

1) Meningkatkan bentuk modul menjadi e modul.

2) Memberikan sumber rujukan pada setiap definisi.

3) Memasukan Undang-Undang terkait Kekerasan Seksual.

4) Menambahkan Informasi mengenai manajemen kebersihan menstruasi.

5) Membuat modul menjadi lebih interaktif dengan menambahkan konten video atau mengganti materi menjadi video.

6) Meningkatkan kuis atau lembar aktivitas menjadi lebih interaktif dengan ditautkan ke link google form.

\section{Uji Coba Produk Awal}

Uji coba dilakukan pada lapangan terbatas yaitu hanya pada 30 orang siswa. Siswa yang menjadi responden diberikan modul dan kuesioner yang telah disusun berdasarkan kisikisi yang telah dibuat. Hasil uji coba produk awal dapat dilihat pada tabel 4.

Tabel 4. Hasil Uji Coba Produk Awal

\begin{tabular}{ccccc}
\hline Aspek Penilaian & $\begin{array}{c}\sum \text { Skor } \\
\text { Diperoleh }\end{array}$ & $\begin{array}{c}\sum \text { Skor } \\
\text { Maks }\end{array}$ & $\begin{array}{c}\text { Persentase } \\
\text { Kelayakan }\end{array}$ & Kategori \\
\hline Kelayakan Isi & 632 & 780 & $81 \%$ & Layak \\
Kelayakan Penyajian & 422 & 480 & $88 \%$ & Sangat Layak \\
Kelayakan Bahasa & 426 & 480 & $89 \%$ & Sangat Layak \\
Total Keseluruhan & 1480 & 1680 & $88 \%$ & Sangat Layak \\
\hline
\end{tabular}

Selain itu, data kualitatif atau catatan yang diberikan responden antara lain sebagai berikut. 
1) Gambar dan tulisan sangat sesuai sehingga saya mengerti saat membacanya.

2) Bagi saya tidak ada catatan atau kritik dan saran karena disini sudah sangat jelas sekali jadi saya faham juga isi gambarnya sangat menarik.

3) Sudah sangat menarik, tapi saya dihitung salah ketika mengerjakan lembar aktivitas karena tidak pakai huruf kapital.

\section{Revisi Produk}

Hasil uji coba produk mencapai $88 \%$ dengan kriteria sangat layak. Kritik yang diberikan siswa mengenai penggunaan huruf kapital dan tidak pada jawaban yang mempengaruhi skor yang diberikan. Peneliti hanya melakukan penelitian sampai tahap hipotetik. Maka dari itu, tahap revisi produk adalah tahap akhir dari penelitian dan pengembangan.

Berdasarkan penelitian pendahuluan yang telah dilakukan, hasil gambaran pengetahuan siswa masih berada dikategori sedang. Artinya, masih terdapat siswa yang kurang memahami pentingnya kesehatan reproduksi bagi dirinya. Maka dari itu, perlu media bimbingan dan konseling untuk membantu layanan informasi yang diberikan kepada siswa, guna meningkatkan pengetahuan kesehatan reproduksi remaja perempuan. Penelitian Prasetiawan (2017) membuktikan bahwa penggunaan media dalam layanan bimbingan dan konseling membantu efektivitas penyampaian layanan.

Berdasarkan hasil uji validasi, modul yang disusun telah mencapai kriteria layak baik dari segi materi maupun media. Secara kuantitatif hasil uji validasi materi mencapai $81 \%$ dan media mencapai $83 \%$. Secara kualitatif kedua ahli mengungkapkan bahwa desain modul memiliki gambar dan warna yang sangat menarik, mudah dipahami dan digunakan. Hal tersebut memenuhi kriteria self-instruction, Depdiknas (2008) menjelaskan self-instruction artinya di dalam modul terdapat lembar penilaian yang membantu siswa melakukan penilaian secara mandiri. Menggunakan bantuan google form siswa dapat melihat skor benar, serta mengetahui jawaban salah pada soal yang telah dikerjakan.

Selain itu, modul juga memenuhi kriterika user friendly dan adaptif. Modul disusun disesuaikan dengan perkembangan teknologi dan ilmu pengetahuan. Hal tersebut didukung dengan pencapaian kelayakan isi mencapai $80 \%$. Kemudahan menggunakan modul karena adanya e-modul serta penggunaan kalimat yang mudah dimengerti penggunanya menunjukan bahwa modul tersebut memenuhi kriteria user friendly. Hal tersebut juga didukung pada uji coba kelayakan bahasa mencapai $89 \%$, artinya responden paham dengan cepat kalimat yang ada pada modul.

Modul yang dikembangkan dibuat full color, sehingga mendapat komentar positif dari ahli media dan siswa. Modul dibuat full color agar memiliki daya tarik untuk dibaca oleh remaja. Penggunaan warna pada modul sejalan dengan pendapat Ashyar (dalam Rusdiana, 2013) bahwa, membangun kemenarikan pada media dan menciptakan respon emosional diperlukan warna. Berdasarkan hasil uji validasi produk penelitian yang berupa modul bimbingan dan konseling kesehatan reproduksi remaja perempuan yang dikembangkan oleh 
peneliti layak diimplementasikan kepada siswa. Hal tersebut didukung juga dengan hasil uji coba produk pada lapangan terbatas sebanyak 30 orang siswa mencapai $88 \%$ artinya modul bimbingan dan konseling tentang kesehatan reproduksi remaja sangat layak untuk diimplementasikan kepada siswa.

\section{SIMPULAN}

Berdasarkan hasil penelitian dan pengembangan yang telah dilakukan, pengetahuan kesehatan reproduksi remaja perempuan kelas IX di SMP Negeri 4 Kota Serang masih berada pada kategori sedang. Sehingga perlu adanya layanan informasi, untuk meningkatkan pengetahuan kesehatan reproduksi remaja perempuan. Peneliti memilih melakukan pengembangan modul bimbingan dan konseling kesehatan reproduksi remaja perempuan, sebagai tindak lanjut dari layanan informasi yang akan diberikan. Penelitian pengembangan yang dilakukan menggunakan model Borg and Gall. Hasil uji ahli materi mencapai dengan kategori "Layak". Hasil uji ahli media mencapai 83\% dengan kategori "Layak". Hasil uji coba produk mencapai $88 \%$ dengan kategori "Sangat Layak". Maka dapat disimpulkan bahwa pengembangan modul bimbingan dan konseling kesehatan reproduksi remaja perempuan merupakan modul yang layak diimplementasikan kepada siswa.

\section{DAFTAR PUSTAKA}

BKKBN. (2001). Program Keluarga Berencana Nasional. Jakarta: BKKBN.

BKKBN, BPS, \& Kemkes. (2018). Survei Demografi dan Kesehatan Indonesia 2017 : Buku Remaja. Dipetik Januari 2020, dari https://e-koren.bkkbn.go.id

Depdiknas. (2008). Pengembangan Bahan Ajar. Sosialisasi KTSP. Dipetik 2020, dari http://dc218.4shared.com

Kusmiran, E. (2011). Kesehatan Reproduksi Remaja dan Wanita. Jakarta: Salemba Medika.

Prasetiawan, H. (2017). Media Dalam Layanan Bimbingan Dan Konseling. Dipetik 2020, dari http://lpp.uad.ac.id

Rosyidah, H., \& Lukitaningsih, R. (2014). Pengembangan Modul Kesehatan Reproduksi Remaja Pada Siswa Kelas X SMAN 1 Menganti.

Rusdiana, E. H. (2013). Pengembangan Modul Pembelajaran Cahaya dengan Pendekatan Keterampilan Proses. Universitas Negeri Semarang. Dipetik 2020, dari lib.unnes.ac.id

Santrock, J. W. (2003). ADOLESCENCE Perkembangan Remaja. Jakarta: Erlangga.

Sugiyono. (2008). Metode Penelitian Pendidikan : (Pendekatan kuantitatif, kualitatif dan R \& D). Alfabeta.

Tjalla, A., Komalasari, G., \& Asharika, E. (2016). Pengembangan Hipotetik Buku Bantuan Diri Tentang Bahaya Merokok. Jurnal Bimbingan Konseling, 5. Dipetik Mei 20, 2020, dari journal.unj.ac.id 
108 | Afriani, Afiati \& Conia - Pengembangan Hipotetik Modul ...

Winarti, E. (2017). Buku Ajar Kesehatan Reproduksi untuk Mahasiswa Kebidanan. Sidoarjo: Indomedia Pustaka. 